\title{
NEW DEVELOPMENTS IN PRECAMBRIAN SEDIMENTOLOGY AND VOLCANOLOGY
}

by

Erich Dimroth

\begin{abstract}
During the next five years, our understanding of Archean volcanic and sedimentary processes and of the diagenesis of Precambrian sedimentary rocks will rapidly advance due to the introduction of uniformitarian process-response models. This article concentrates on some of the most promising areas of research - flow mechanisms and facies distribution of subaqueous volcanic flows, paleogeographic analysis of Archean greenstone belts, diagenesis of Precambrian cherts, and the Precambrian atmosphere. Current research in these fields has major implications for mineral exploration.
\end{abstract}

\section{Introduction}

IGCP Project 160 on "Precambrian Exogenic Processes", organized between 1977 and 1979 by Jan Veizer, became fully operational at its first general meeting in Québec, Canada in May of 1979. It is concerned with the sedimentology and volcanology of Precambrian rocks and their alteration during diagenesis. The results of research conducted under this Project suggest that we are at the brink of a major breakthrough which may fundamentally affect some concepts of Precambrian geology.

The progress made in the study of volcano-sedimentary terrains and diagenesis is due largely to the applications of uniformitarian process-response models. The philosophy of this uniformitarian approach is simple and widely used. While we can observe the structure and organization of ancient rocks we cannot observe the processes responsible for their formation. Nevertheless, currently active processes may be studied which produce structures and forms of organization identical to those observed in ancient rocks. Through comparisons, it is possible to reconstruct the processes which gave rise to some specific forms and structures seen in Precambrian exposures. As a result, rapid progress is now being made in understanding the volcanology and sedimentology of volcano-sedimentary terrains, and in the field of diagenesis of Precambrian sedimentary and volcanic rocks.

\section{Volcano-Sedimentary Terrains \\ Volcanology}

Comparison of ancient submarine lavas (Dimroth and Rocheleau, 1979; Hargreaves and Ayres, 1979; de Rosen-Spence et al., 1980) with Quaternary subaqueous basalt flows (Moore et al., 1972; Moore, 1975; Ballard and Moore, 1977; Ballard et al., 1979) demonstrates that the lava-delta is a common feature of subaqueous lava flows (Fig. 1). Most Archean lava flows consist of a proximal facies of massive lava which grades downcurrent into the pillowed facies by ramification into numerous curving and branching lava tubes. These tubes, as well as the buds formed by extrusion of lava from cracks at the surface of lava tubes, are called "pillows". The flowfront is foreset bedded, and consists either of pillow basalt, or of alternating foresets and topsets of pillows (lava tubes), lobes of massive lava, and pillow breccia.

Where the terrain is very flat, the massive lava occupies a pancake-shaped proximal domain (Fig. 1, A). On gently sloping shields, the massive lava fills broad valleys; on somewhat steeper shields it fills braided constructional channels (Fig. 1, B) which may be quite narrow. As the flow builds up, old valleys are filled and abandoned, new valleys form between the active lava flows and are re-occupied as the old channels are abandoned. Furthermore, the rate of lava flow decreases toward the termination of an eruption, so that more distal facies (pillows or pillow breccia) come to rest on more proximal facies (massive lava) towards the top of a flow.

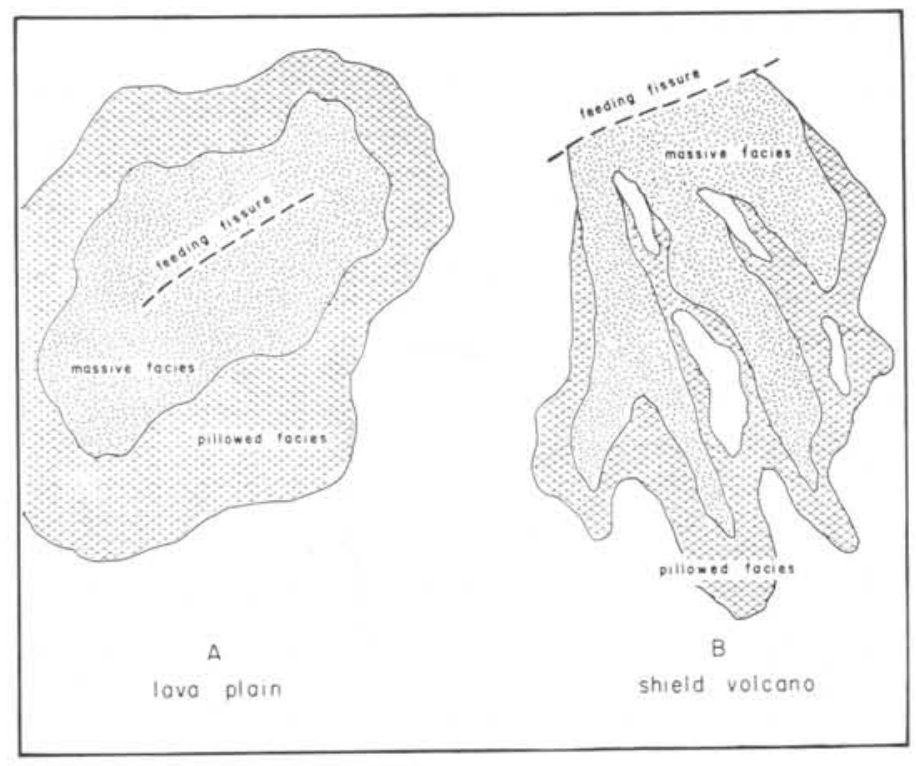

Figure 1. Facies distribution of subaqueous lava flows. A proximal massive facies grades laterally into a distal pillowed facies. A-facies distribution on subaqueous lava plain; B facies distribution on flat subaqueous shield.

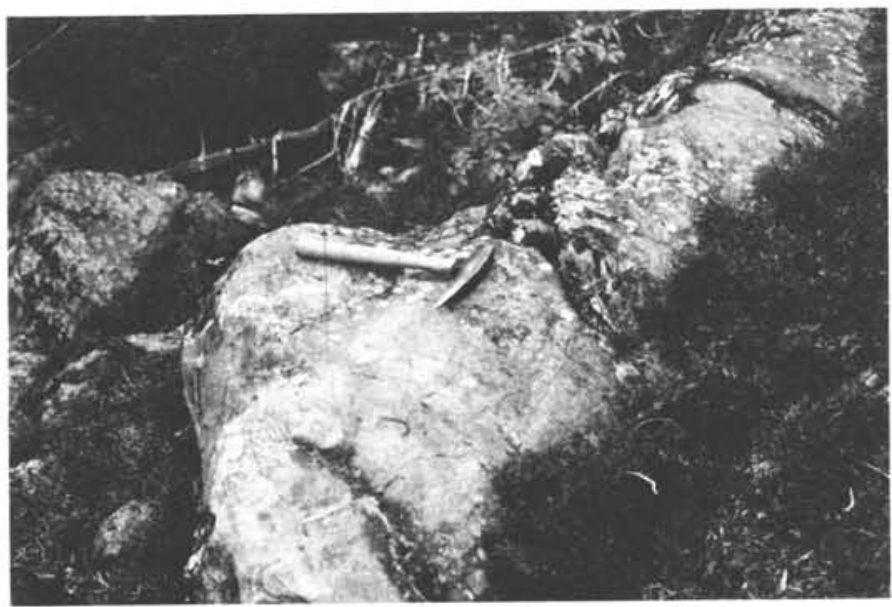

Basalt pillows exposed in three dimensions. The pillow is in fact a lava tube, branching in the direction away from the observer at the hammer. One branch (to the left and broken away) is above the hammer handle, the other (preserved) on top of the hammer head. Amulet Andesite, Noranda, Quebec. (Photo courtesy P. Cousineau) 
This model permits one to interpret the vertical and lateral facies changes in lava flows in terms of the evolution of volcanic complexes (Fig. 2). Such interpretations are aided, for example, by measurements of paleo-flow directions, from the symmetry of strongly elongated pillows (lava intersected sub-parallel to their long axis), by branching lava tubes, and by foreset-bedding of pillows and pillow breccias.

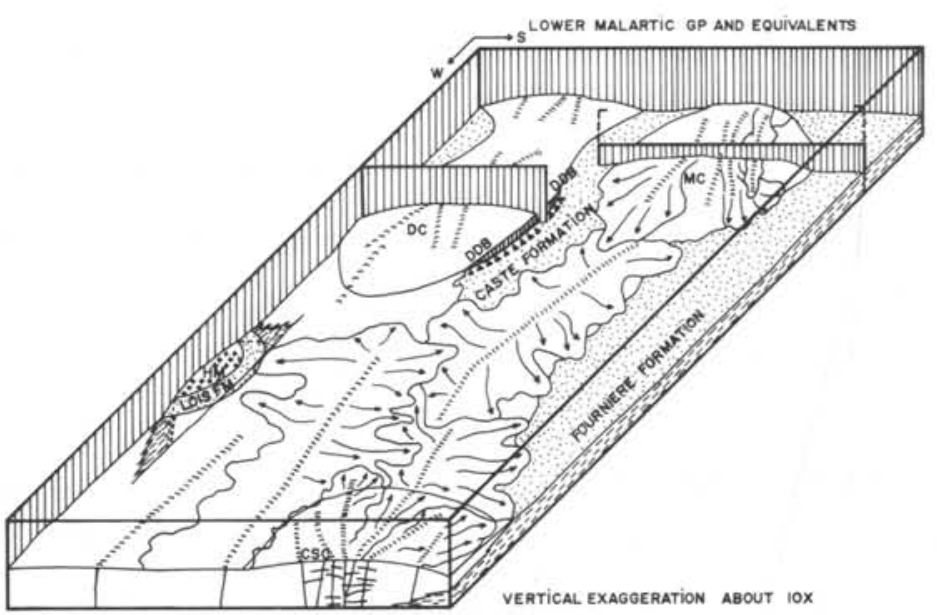

Figure 2. Physiography of the south-central Abitibi belt area at the time of eruption of the lowermost Malartic Group and its equivalents: a lava plain with marginal central volcanic complexes. (These lavas were extruded approximately 2700 Ma ago in the Late Archean).

Pyroclastic rocks are potentially an equally powerful tool of paleo-volcanological analysis, but there is still much to learn about their origin. The emplacement mechanism of pyroclastic rocks, however, may be recognized by their sedimentology (Schmincke, 1974; Lajoie, 1979) and petrographic comparison of the ejecta in ancient and Holocene pyroclastic rocks permits recognition of the probable eruptive mechanism (Heiken, 1972; Dimroth, 1977). Much work has yet to be done before we will be able to establish general facies models.

\section{Sedimentology}

There is general agreement that the bulk of the terrigenous Archean sediments has been deposited in steep-sloped basins. Sediments from high-gradient streams (piedmont fan, braided streams) grade directly into turbidites of deep-marine fan systems (Hyde, 1980; Eriksson, 1980); very commonly the sedimentary basins are separated from volcanic chains by growth faults (Fig. 3). On the other hand, such steep-sloped,

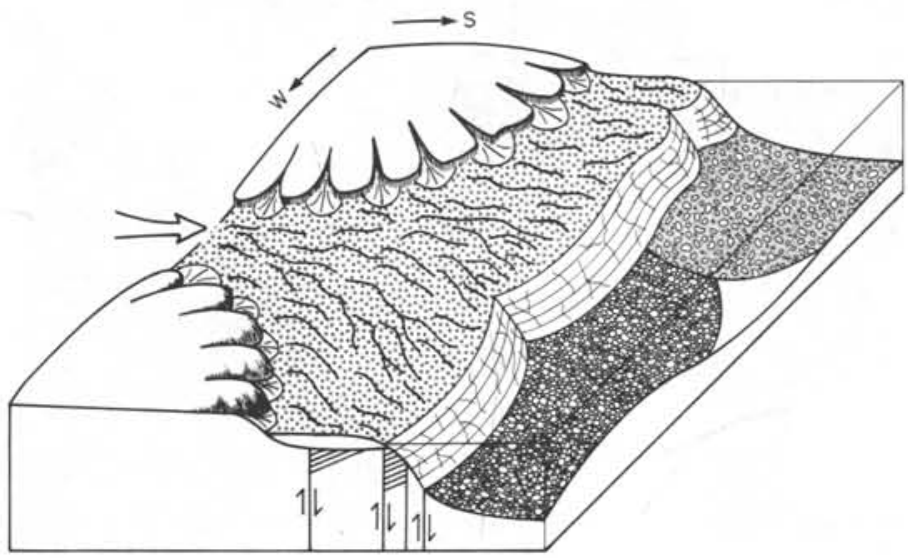

Figure 3. Physiography of the Rouyn-Noranda area at the time of emergence of volcanic islands. Braid plain deposits and some volcanic activity on islands. Steep sedimentary slopes leading to turbidite fans. tectonically active, basin margins have very rarely been transformed into passive shelf-rise basin margins by progradation of turbidite fans (Eriksson, 1980).

Interflow sediments, of shallow water marine origin in the volcanic sequences in Western Australia (Barley et al., 1979), South Africa (Lowe and Knauth, 1977) and NW Canada (Henderson, 1975) are particularly puzzling. These are mainly limestones which, very commonly, have been silicified. Sabkha cycles, stromatolites, oolites, are characteristically present. The volcanology of the volcanic rocks within which they occur has not been studied, so that we have attained no true understanding of their significance. Curiously, these rocks have been reported only from localities where the volcanic rocks are underlain by a sialic basement.

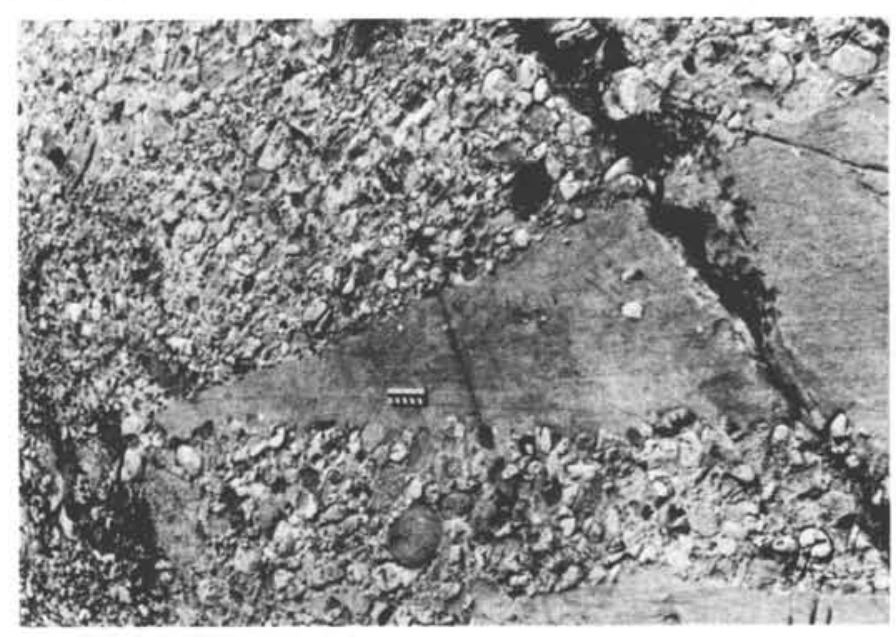

Erosion channel, filled by conglomerate, cutting arkose with parallel lamination. Timiskaming Group, Chaput Hughes, Ontario. (Photo courtesy M. Rocheleau)

\section{Paleogeographic Evolution}

Reconstruction of the paleogeographic evolution of Archean greenstone belts should receive high priority in Precambrian research. Present interpretations of the geotectonics of Archean greenstone belts tend to be based on chemical data. This is too narrow a basis for sound interpretation, though geochemical data will acquire a new and much greater significance once they can be evaluated in their paleogeographic context.

Paleogeographic analysis requires the integration of volcanological and sedimentological data into a stratigraphic framework. Research in several areas in Canada (western Ontario and eastern Manitoba, parts of Slave Province, the Abitibi belt) should be advanced enough to permit this within the next few years. A closer look at the south-central Abitibi belt of the province of Québec and Ontario will serve to illustrate this.

The belt grew as a volcanic chain bounded to the south by a sedimentary basin. Within the volcanic chain, two paleogeographic elements may be distinguished - basalt platforms and central volcanic complexes. During emergence, fluvial sediments (and locally, subaerial volcanic rocks) were deposited on the volcanic chain. The sedimentary basin to its south was also composed of two paleogeographic elements - an upper part of turbidite fans (conglomeratic mass flows and greywacke turbidites), and a lower part of turbidite fans composed of monotonous greywackes. The evolution of such a system is demonstrated in Figures 2 and 3 which show both early and late stages of the evolution of the south-central Abitibi belt.

At an early stage in its evolution, the volcanic chain consisted of a large basalt platform, marginal to which central volcanic complexes developed (Fig. 2). Whether the sedimentary basin already existed at this stage is a moot 
question. The volcanic sequence was komatiitic and tholeiitic. Differentiated rocks (tholeiitic andesites, dacites, rhyolites), everywhere subordinate, were concentrated in the central volcanic complexes.

As the volcanic chain evolved, central volcanic complexes expanded until they occupied the whole terrain. Their chemistry also evolved from tholeiitic to cal-alkalic suites (Jensen, 1978; Gélinas et al., 1977). In the final stages, the volcanic chain emerged and growth faults developed at the boundary with the sedimentary basin (Fig. 3). Braided stream deposits accumulated on the volcanic chain. Contemporaneous volcanism was relatively minor, calc-alkalic and, at specific times, alkalic, while turbidite fans prograded southward in to the sedimentary basin.

The evolution of the south-central Abitibi belt is similar to that of an island arc-forearc basin system. This is not to say that the belt can be considered a "model" of an Archean greenstone belt, nor that all Archean greenstone belts are similar: on the contrary, Archean greenstone belts probably formed in a number of different geotectonic situations, and specific types of greenstone belts may be found to be related to their paleogeographic evolution.

\section{Diagenesis}

Recent work on the diagenesis of Precambrian sediments has focussed on different aspects of this process: soils and sea floor weathering, cherts and iron formations, red beds, diagenetic sulfates and sulfate-reduction, diagenesis of carbonates and of organic matter. Only two of these areas of research are highlighted below - the origin of cherts and the Precambrian a tmosphere.

\section{Cherts}

Work done by sedimentologists at Louisiana State University, U.S.A. (Lowe and Knauth, 1977) and by several workers at the University of Western Australia (Barley, Dunlop, Grover, personal communication) leaves little doubt that most Archean cherts are silicified limestones and tuffs. Silicified peritidal limestones are easily recognized by characteristic vertical sequences of sedimentary structures. Cherts with oolitic and intraclastic textures, flat-pebble conglomerates, various types of stromatolites are parts of such vertical sequences. Particularly important are vertical structure sequences containing evidence of the former presence of evaporites (gypsum, anhydrite, halite), as well as dolomite, in what is called sabkha cycles.
Cherts derived from tuffs are easily recognized where they contain large $(>0.5 \mathrm{~mm})$ relict textures of pumice, bubblewall shards, or hyaloclastic granules, or where they contain accretionary lapilli (as, for example, in the Msaulli "Oolite" of the Barberton Mountainland). Crystals of quartz and feldspar are generally present in such silicified tuffs. It is more difficult to recognize the origin of thin-bedded deepwater cherts, originally composed of finely particulate calcite (micrite) or of very fine-grained volcaniclastic debris. These rocks very commonly show graded bedding and are often Bouma-cycled which proves that deposition was in the form of non-cohesive, fine-grained particulate matter. While it is possible to deduce that such rocks were never composed of silica-gel, it is difficult to determine the original nature of particles which were so fine-grained that their outlines are now not clearly recognizeable.

\section{The Precambrian Atmosphere}

Evidence is quickly accumulating to indicate that the earth's atmosphere was strongly oxygenated since very early Precambrian time. Most pertinent in this respect are the description of Archean red-beds (Shegelski, 1980), the comparison of Precambrian weathering on land (soils: Koryakin, 1977; Sochava et al., 1975; Gay and Grandstaff, 1980) and under the sea (sea-floor weathering: Dimroth and Lichtblau, 1979; Dimroth and Rocheleau, 1979) with modern weathering phenomena, and the re-interpretation of the Precambrian pyritic conglomerates in the light of new evidence (Simpson and Bowles, 1977; Kimberley, 1980; Clemmey, personal communication).

Detailed descriptions of Proterozoic soil profiles, though not numerous, are now available. They show that Precambrian soils are quite comparable to Holocene soils. This is true even for the iron-depleted soils below the Huronian (Proterozoic).

Considering the paleogeographic environment, it is not likely that Archean soils will be found at many locations. All Archean submarine basalts and rhyolites, however, suffered sea-floor alteration. The study of petrographical relicts has led to the identification of those minerals which were originally formed by Archean sea-floor alteration (Dimroth and Lichtblau, 1979); these relicts permit correlation of the chemistry and petrography of the alteration products (Fig. 4).

Strong iron enrichment of the rim zone of basalt pillows combined with enrichment of $\mathrm{Mn}$ and $\mathrm{K}$ is due to the

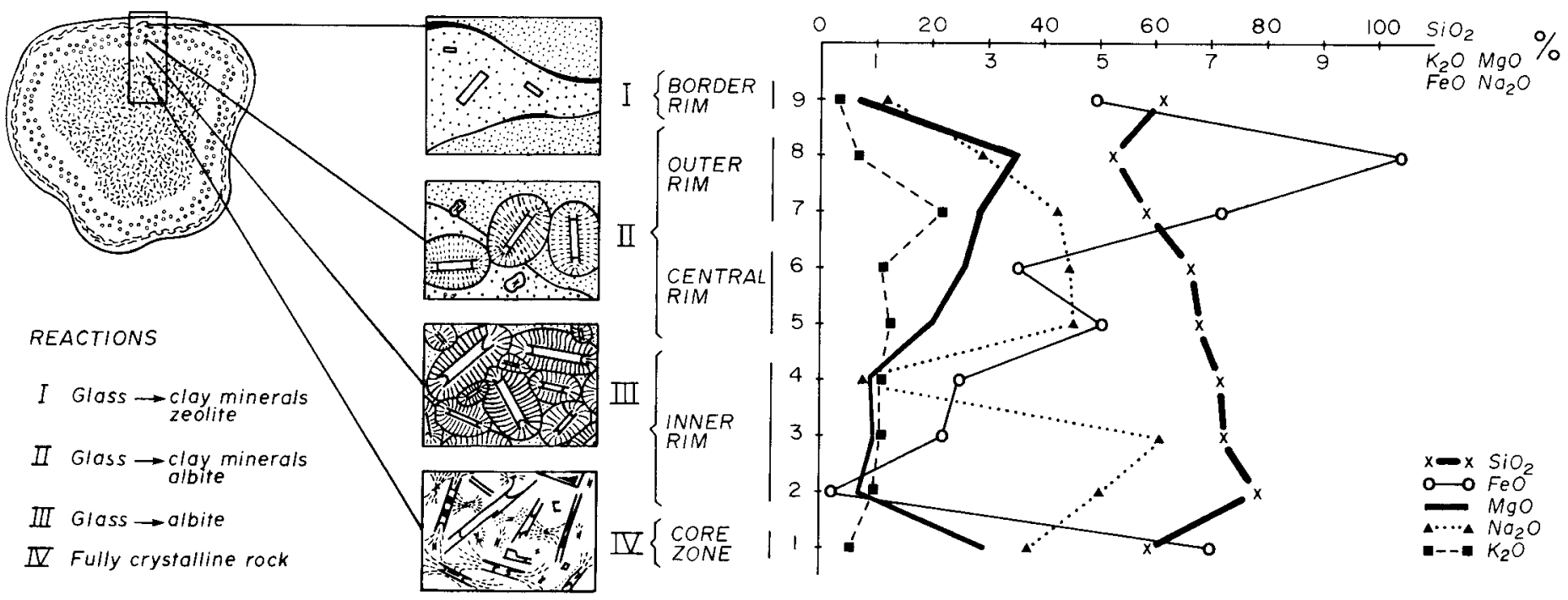

Figure 4. Sea-floor alteration of pillows. The glassy skin of pillows, was transformed to clay minerals and zeolites, the spheralitic rim to mostly albite feldspar. All minerals were later replaced by metamorphic products. Note the major-element distribution, analogous to the alternation pattern of modern, highly altered sea-floor pillows. 
precipitation of iron oxides and of ferric and $\mathrm{K}$-rich clay minerals (celadonite) in environments of high oxygen concentration.

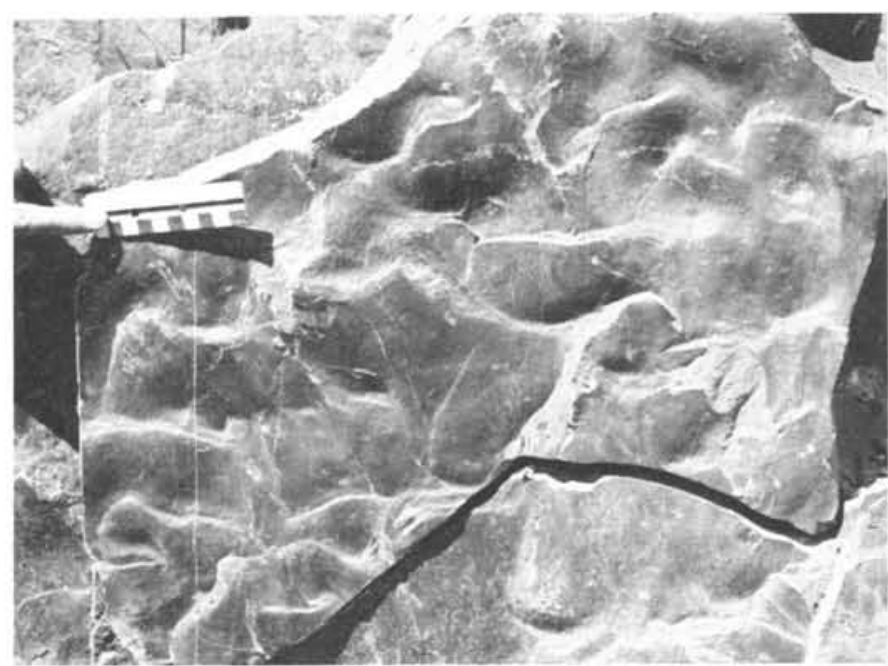

Asymmetric ripple marks in flood plain (or lacustrine?) deposits. View on bedding plane. Duparquet Formation, Noranda, Quebec. (Photo courtesy M. Rocheleau)

Our view of the significance of the Witwatersrand-type uraniferous and pyritic conglomerates is also changing rapidly. Clemmey (personal communication) is investigating the weathering of sulfides, the sedimentary concentration of pyrite in placers (Atakama and Namib deserts) and their diagenetic changes after deposition. Simpson and Bowles (1977), Dimroth (1979) and Kimberley (1980) are studying the diagenesis of Witwatersrand-type ores. From the results of all these studies, it has become obvious that the Witwatersrand ores are not simply placers that suffered some "metamorphic" remobilization. The concentration processes were extremely complicated and the interaction of diagenetic and placer enrichment processes both played a role in the origin of these ores. But the data do not provide evidence for a reducing atmosphere; rather, they indicate that these processes can take place only in the presence of substantial concentrations of oxygen.

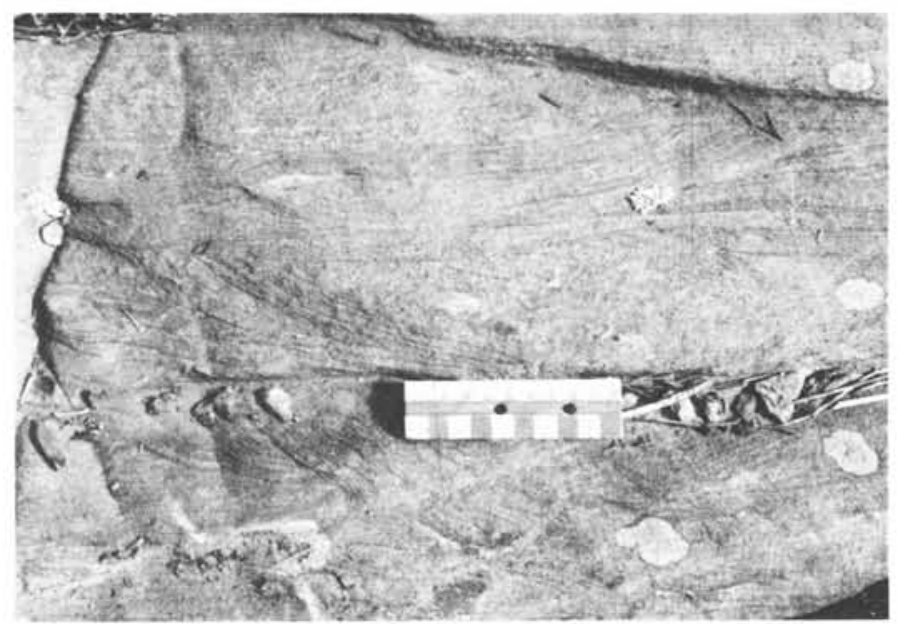

Trough-cross-bedded fluvial arkose. Note isolated pebbles. Granada Formation, Noranda, Quebec. (Photo courtesy M. Rocheleau)

\section{Metallogenetic Significance}

Ongoing research in Precambrian volcanology and sedimentology will lead to the development of more precise genetic models of sedimentary and volcanic ore deposits, which may change the emphasis in strategies of mineral exploration in
Precambrian terrains. A closer look at massive volcanogenic sulfide deposits might illustrate this point.

It has long been known that these deposits are the product of submarine exhalative activity. The fact that the stratigraphy and location of these deposits is determined by volcanological factors is equally well known. For example, at Noranda (in northern Québec, Canada), most of the deposits are located within or at the margin of a large caldera, and most deposits formed during the period of caldera collapse (Spence and de Rosen-Spence, 1975). Furthermore, it now appears that the circulation of hydrothermal brines depositing these metals was caused by shallow intrusions, generally of acidic composition, within faults in and at the margin of the caldera.

A model for the origin of these deposits is presented as Figure 5. The hydrothermal brines are discharged in small localized areas, controlled by syn-volcanic faults and by small intrusive bodies. The recharge area for these convection cells is very large. Heavy metals are leached from the volcanic rocks during oxidizing sea-floor metamorphism. Thus, the metals leached from a very large volume of volcanic rock are concentrated at one single location by the convection cell.

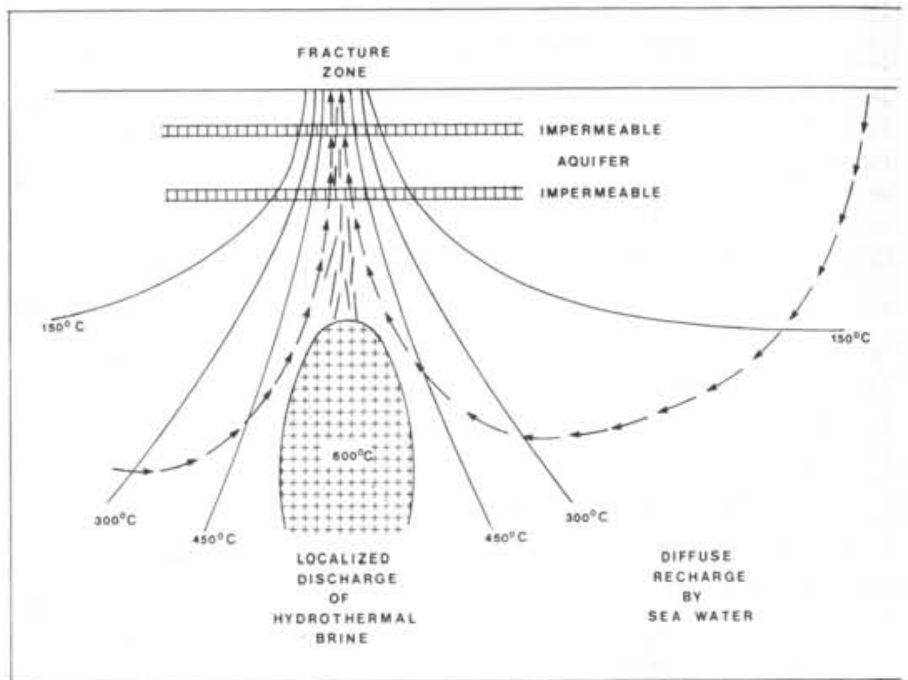

Figure 5. Brine circulation system during deposition of the Archean massive $\mathrm{Cu}-\mathrm{Zn}$ deposits. Shallow intrusive bodies generally of felsic composition-function as the pump. Heavy metals are leached from volcanic rock by cold, oxygenated sea-water; they flow toward the intrusive bodies where they are heated; they rise in fracture zones above the intrusive bodies.

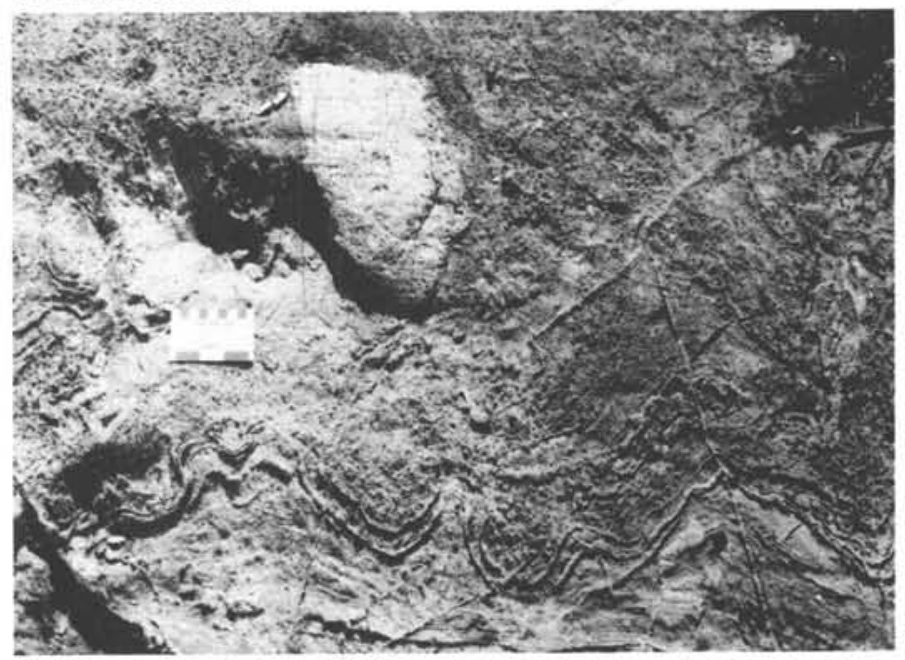

Fall-back block in ash tuff. Ash tuff below fall-back block shows convolute lamination. Powell Tuff, Noranda, Quebec. (Photo courtesy A.P. Lichtblau) 
Such a genetic model of ore deposition has predictive value. The location of the ore deposits is not restricted to one single stratigraphic interface, as was previously believed, but is determined by syn-volcanic faulting and the coincident intrusion of magmatic bodies within these faults. Most ore deposits are situated within the caldera simply because most syn-volcanic faults formed within it during, and because of, the caldera collapse.

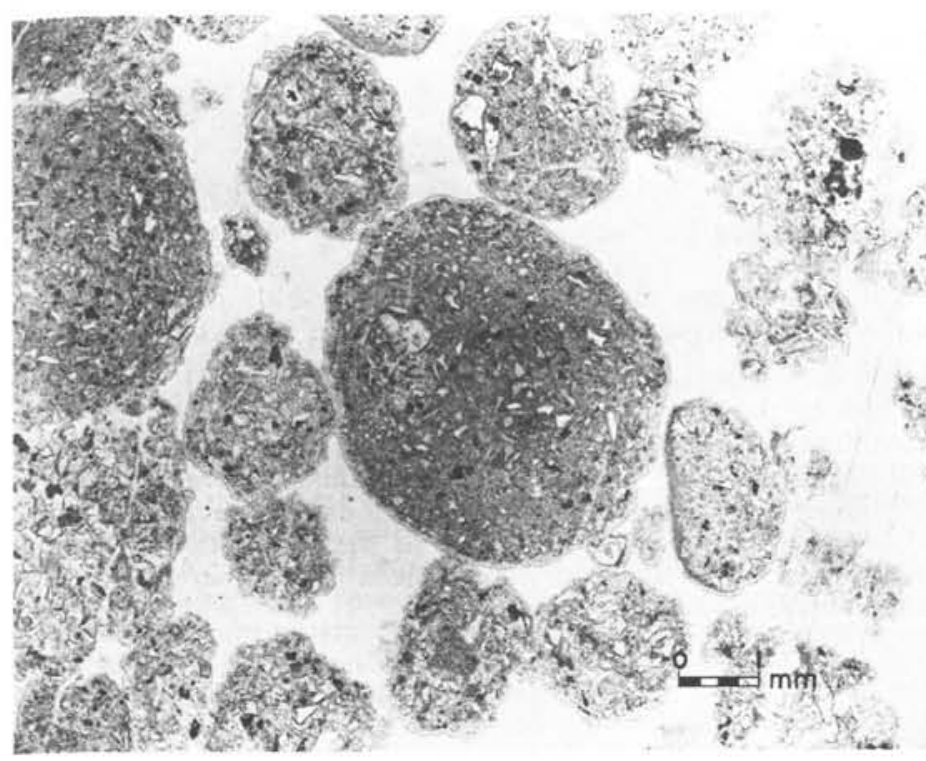

Silicified accretionary lapilli in Archean chert. Barberton Mountainland, South Africa. Section A 123-69C from E.C. Perry. This section is $1.5 \mathrm{~cm}$ across. (Photo courtesy R.C. Bald)

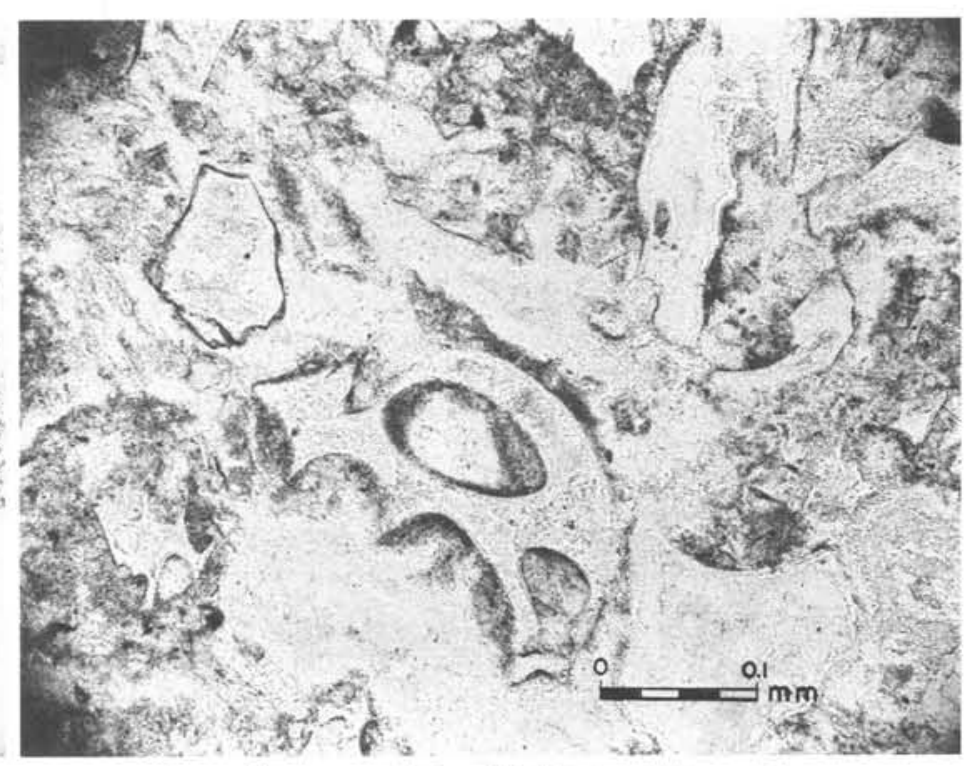

Detail from figure on left: silicified bubble-wall shard. A small quartz splinter to its lower right. The bubble-wall shard is $0.2 \mathrm{~mm}$ across. (Photo courtesy R.C. Bald)

\section{References}

Ballard, R.D., Holcomb, D.T. and Van Andel, T.H., 1979, The Galapagos Rift at $86^{\circ} \mathrm{W}, 3$, Sheet flows, collapse pits and lava lakes of the rift valley: 3 . Geophys. Res., v. 84 , p. $5407-5422$.

Ballard, R.D. and Moore, J.G., 1977, Photographic Atlas of the Mid-Atlantic Rift Valley: Springer Verlag, New York, N.Y.

Dimroth, E., 1977, Archean autoclastic volcanic rocks: Classification diagnosis and interpretation: Geol. Surv. Can., Pap. 77-1A, p. 513-522.

Dimroth, E., 1979. Role of diagenesis in the origin of Witwatersrand-type uraniferous conglomerates: Phil. Trans. R. Soc. London, v. A291, p. 277-287.

Dimroth, E. and Lichtblau, A.P., 1979, Metamorphic evolution of Archean hyaloclastites, Noranda area, Québec, Canada: Part 1: Comparison of Archean and Cenozoic sea-floor metamorphious: Can. J. Earth Sci., v. 16, P. $1315-1340$.

Dimroth, E. and Rocheleau, M., 1979, Field trip A I: Volcanology and Sedimentology of Rouyn-Noranda area, Québec: GAC/MAC, Université Laval, Québec, 198 p.

Eriksson, K.C., 1980. Transitional sedimentation styles in the Moodies and Fig Three Groups, Barberton Mountainland. South Africa: Precambrian Research, in press.

Gay, A.L. and Grandstaff, D.E., 1980, Chemistry and mineralogy of Precambrian paleosols at Elliot Lake, Ontario, Canada: Precambrian Research, in press.

Gelinas, L., Brooks, C., Perreault, G., Carignan, J., Trudel, P. and Grasso, F., 1977, Chemo-stratigraphic division within the Abitibi volcanic belt, Rouyn-Noranda district,
Québec, in Baragar, W.R.A., Coleman, L.C. and Hall, J.M. (eds.), Volcanic regimes in Canada: Geol. Assoc. Can. Spec. Pap. 16, p. 297-310.

Hargreaves, R. and Ayres, L.D., 1979, Morphology of Archean metabasalt flows, Utik Lake, Manitoba: Can. J. Earth Sci., v. 16, p. 1452-1466.

Heiken, G., 1972, Morphology and petrography of volcanic ashes: Geol. Soc. Amer. Bull., v. 83, p. 1961-1988.

Henderson, J.B., 1975, Archean stromatolites in the northern Slave Province, Northwest Territories, Canada: Can. J. Earth Sci., v. 12, p. 1619-1630.

Hyde, R.S., 1980, Sedimentary facies in the Archean Timiskaming Group and their tectonic implications, Abitibi Greenstone Belt, Northeastern Ontario, Canada: Precambrian Research, in press.

ensen, L.5., 1978, Archean komatiitic, tholeiitic, calcalkalic and alkalic volcanic sequences in the Kirkland Lake area, in Currie A.L.. and W.O., Mackasey, (eds.). Toronto 178: field trip guidebook, p. 227-259.

Kimberley, M.M., Tanaka, R.T. and Farr, M.R., 1980, Composition of middle Proterozoic uraniferous conglomerate in the Elliot Lake Agnew Lake area of Canada: Precarnbrian Research, in press.

Koryakin, A.S., 1977, Dokembriyckiye metamorfisovanie Kor: vivelivaniya Karelii, in Problemi covremennoi citologii i osadochnikh polesnikh iskopayemikh: Akademia Nauk SSSR, Novosibirsk, 1977, p. 72-80.

Lajoie, J., 1979, Facies models - 15. Volcaniclastic rocks Geoscience Canada, v. 6, p. 129-139.

Lowe, D.R. and Knauth, L.P., 1977, Sedimentology of the
Onverwacht Group (3.4 billion years), Transvaal, South Africa, and its bearing on the characteristics and evolution of the early earth: J. Geol., v. 85, p. 699-723.

Moore, J.G., 1975, Mechanism of formation of pillow lava: Amer. Scientist, v. 63, p. 269-277.

Moore, J.G., Phillips, R.L., Grigg, R.W., Peterson, D.w. and Swanson, D.O., 1973, Flow of lava under the sea, 1969 1971, Kilauea Volcano, Hawaii: Geol. Soc. Amer. Bull., v. 84, p. $537-546$.

Rosen-Spence, A.F. de, Provost, G.. Dimroth, E., Owen, v. and Gochnauer, K., 1980. Archean subaqueous felsic flows and their Quarternary equivalents: Precambrian Research, in press.

Schmincke, H.-U., 1974, Pyroclastic Rocks, in H. Fuchtbauer, Sediments and sedimentary rocks: Schweizerbart'che Verlagsbuchhandlung, Stuttgart, v. 1, p. 160 . 189.

Shegelski, R.J., 1980, Archean cratonization, emergence and red bed development, Lake Shebandowan area, Canada: Precambrian Research, in press.

Simpson, P.R. and Bowles, J.F.W., 1977, Uranium mineralization of the Witwaterstand and Dominion Reef systems: Phil. Trans. R. Soc. (London), v. A286, p. 527-548.

Sochava, A.V., Savelyev, A.A. and Shulesko, T.K., 1975, Kaliche $\mathrm{v}$ credneproterosoickikh otlosheniyakh zentralnoi Karelii: Doklady Akademii Nauk SSSR, v. 223, p. 14511454

Spence, C.D. and de Rosen-Spence, A.F., 1975, The place of sulphide mineralization in the volcanic sequence at Noranda, Québec: Econ. Geol., v. 70, p. 90-101.

ABOUT THE AUTHOR: Project Leader of IGCP Project 160 ("Precambrian Exogenic Processes"), Erich Dimroth is Professor of Geology at the Université du Québec in Chicoutimi, Canada. Professor Dimroth's main research interests lie in the volcanic and sedimentary evolution of Precambrian geosynclines and their comparison with Mesozoic-Cenozoic tectonic units.

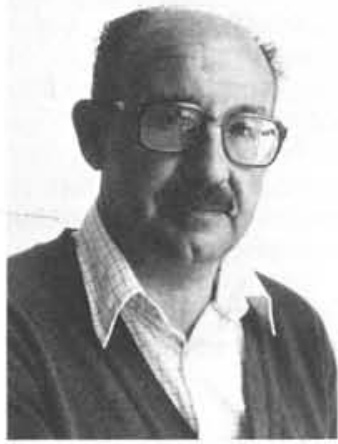

